\title{
Epitheliotropic lymphoma with heart and kidney metastasis in a dog: case report
}

\author{
[Linfoma epiteliotrópico em cão com metástase cardíaca e renal: relato de caso] \\ C.M.T.D. Araújo, B.D. Pacheco, J.L.C. Castro, M.R. Farias, J.R. Engracia Filho* \\ Pontifícia Universidade Católica do Paraná - PUCPR - Curitiba, PR
}

\begin{abstract}
A female adult dog, with a four-month history of pain and intense pruritus, which eventually resulted in sudden death, was referred for necropsy. Postmortem examination showed thoracic and abdominal serumsanguineous exudates, multifocal infiltrative renal masses, and similar tumors in the heart. Histopathology revealed midsize infiltrative neoplastic proliferation composed of round cells, sparse cytoplasm, and large hyperchromatic nuclei. Immunohistochemistry revealed $\mathrm{CD} 3+$ and $\mathrm{CD} 20$-immunoexpression. Histopathological and immunohistochemical findings confirmed the diagnosis of epitheliotropic lymphoma with cardiac and renal metastasis.
\end{abstract}

Key-words: metastasis, lymphoma, cutaneous, canine, necropsy

\section{RESUMO}

Foi encaminhado para necropsia um cão adulto do sexo feminino, com histórico de dor e prurido intenso com evolução de quatro meses, que acabou resultando em morte súbita. O exame post mortem mostrou presença discreta de exsudato serossanguinolento em cavidades torácica e abdominal, massas renais infiltrativas multifocais e tumores semelhantes no coração. O exame histopatológico revelou proliferação neoplásica infiltrativa composta de células redondas, com citoplasma escasso, e grandes núcleos hipercromáticos. A análise imuno-histoquímica mostrou imunoexpressão CD3+e CD20. Os achados histopatológicos e imuno-histoquímico confirmaram o diagnóstico de linfoma epiteliotrópico com metástase cardíaca e renal.

Palavras-chave: cão, metástase, linfoma, cutâneo, necropsia

\section{INTRODUCTION}

Canine cutaneous epitheliotropic lymphoma (CEL) is a neoplastic condition of unknown etiology that has frequently been reported in dogs and cats. This condition is usually characterized by infiltration of malignant $\mathrm{T}$ cells with a specific tropism for epidermal structures (Fontaine et al., 2010). Both human and canine CEL are composed of memory $\mathrm{T}$ cells, which supports the hypothesis that chronic antigen stimulation may trigger the production of a clonal neoplastic $\mathrm{T}$ cell population in the skin, whereas canine cutaneous epitheliotropic lymphoma predominantly develops in areas

Recebido em 10 de julho de 2016

Aceito em 13 de dezembro de 2016

*Autor para correspondência (corresponding author)

E-mail: jair.engracia@pucpr.br commonly affected by inflammatory conditions, such as atopic dermatitis (Gross et al., 2005). The most common types of lesions observed were erythema $(86.6 \%)$, plaques $(73.3 \%)$, erosions $(60 \%)$, scales $(60 \%)$, nodules $(53.3 \%)$, hypopigmentation $(50 \%)$, and involvement of the mucosa was observed in $50 \%$ of the cases (Fontaine et al., 2010).

The histopathological diagnostic pattern for CEL is the tropism of neoplastic cells for the epidermal or mucosal epithelium and the adnexal structures, in particular the follicular wall. The intraepithelial neoplastic lymphocytes are either diffusely distributed within the epithelium or form discrete aggregates (Gross et al., 2005). 
Few studies have shown the occurrence of primary CEL in organs other than the skin (Fontaine et al., 2010). So far only six cases were described in veterinary literature of CTCL with organs metastasis, being four cases in a dog, one in a chipmunk and one in a guinea pig (Czasch et al., 2000; Fictum et al., 2009; Panakova et al., 2009; Martorell et al., 2011; Yoon et al., 2014; Mineshige et al., 2016). This study aims to describe the case of a dog that exhibited a rare manifestation of CEL with multiple organ metastasis, which may have progressed to a paraneoplastic syndrome resulting in mortality.

\section{CASE REPORT}

A female, adult dog was referred for necropsy to the Department of Veterinary Pathology (Pontifícia Universidade Católica do Paraná PUCPR, Brazil) with plaques and erythematous nodules with eroded and ulcerated surfaces on the face, neck, and abdominal areas (Fig. 1), with an evolution period of four months. The animal had a history of pain and intense pruritus, and had sudden death.
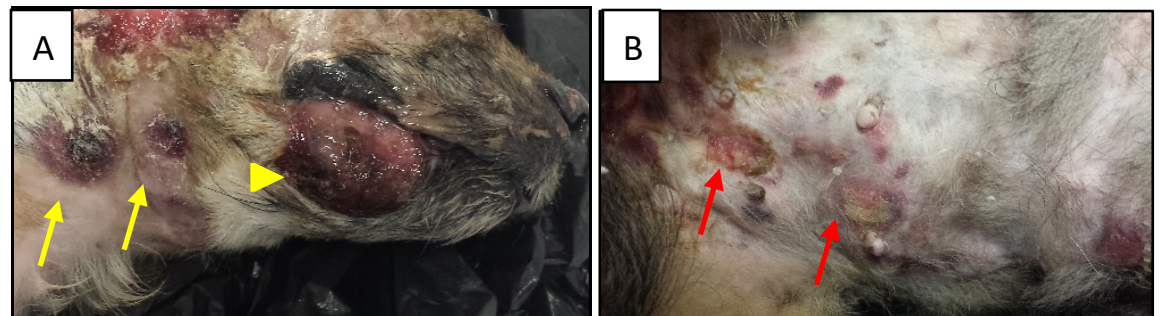

Figure 1. Skin lesions on the face and neck (A) and on the abdomen (B). Ulcerative infiltration is observed in the right mandibular area and lips (arrow head). Hematomeliceric crusts in the erythematous nodules (yellow arrow) and ulcerated plaques (red arrow) associated with serum-sanguineous exudation.

At necropsy, in addition to the skin lesions, severe suppurative otitis and mild chest and abdominal serum-sanguineous exudation were seen. The kidneys presented multifocal infiltrative nodules, irregular edges and whitish in color, which extended from the cortex to the medulla (Fig. 2A). Lesions similar to those observed in the kidneys were present in the myocardium, affecting the entire length of the interventricular septum, two-thirds of the right ventricle, and the left ventricular wall (Fig. 2B). The endocardium was thickened, with a fibrous appearance. No other gross abnormalities were observed. Samples of the skin, heart, and kidneys were collected and fixed in 10\% formalin. The tissue samples were embedded in paraffin, and 4$\mu \mathrm{m}$-thick sections were cut and stained with hematoxylin and eosin using standard histopathological procedures.

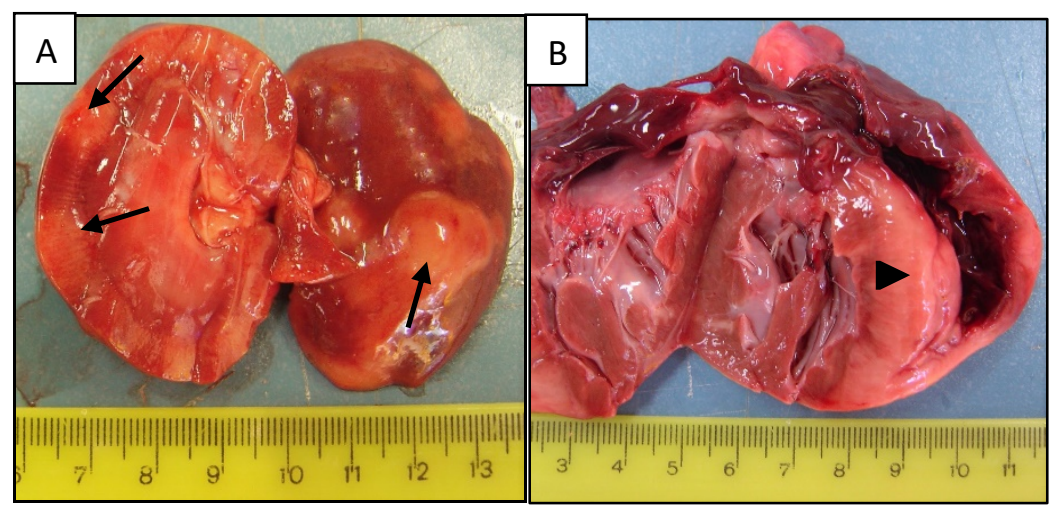

Figure 2. (A) Multifocal infiltrative white masses in the cortex of the kidney (arrow). (B) Infiltrative white proliferation in the interventricular sept and part of the right ventricule (arrow head). 
Histopathological findings in the skin showed infiltrating neoplastic lymphocytes in the epidermis, dermis and follicular epithelium. Several Pautrier's microabscesses, composed mainly of lymphocytes, were observed in the epidermis and subepidermal areas (Fig. 3A). Histopathology of heart and kidneys showed growths composed of round medium-sized cells in the affected areas. The cells showed scant cytoplasm and large hyperchromatic nuclei. Moderate anaplasia and discrete cellular monotony were observed (Fig. 3B).

Immunohistochemical analysis was performed on paraffin-embedded sections, the samples were deparaffinized and rehydrated. Endogenous peroxidase was inhibited with $5 \% \quad \mathrm{H}_{2} \mathrm{O}_{2}$ in methanol for $15 \mathrm{~min}$, followed by antigen retrieval with the Target Retrieval Solution ${ }^{\mathrm{TM}}$ (Dako, Glostrup, Denmark) in a water bath at $90^{\circ} \mathrm{C}$. The samples were incubated with antibodies against T-cell (Dako ${ }^{\circledR}$ Monoclonal Mouse anti-CD3 Clone F7.2.38) and B-cell (Monoclonal Mouse anti-CD20 Clone L26) with PBS. As a negative control, PBS was added instead of the antibody. Advance ${ }^{\mathrm{TM}}$ (Dako, Glostrup, Denmark) was used as a secondary antibody, and immune reactions were completed with the chromogen DAB 1.1 (OriGene, Rockville, MD, USA), followed by counterstaining with Harris hematoxylin.

Immunohistochemical examination showed CD3+ and CD20- immunoexpression of neoplastic cells (Fig. 4). The immunohistochemistry findings were the same for skin, heart and kidney.

\section{DISCUSSION}

In this case, the histopathological and immunohistochemical findings are consistent with cutaneous epitheliotropic lymphoma. The most characteristic lesion common to all forms of canine cutaneous $\mathrm{T}$ cell lymphoma is the tropism of neoplastic cells in the epithelium (Fontaine et al., 2010). The classic neoplastic cells in canine cutaneous epitheliotropic lymphoma are CD3+ and CD20- cells (Martorell et al., 2011; Machado et al., 2015). More recently, Brachelente et al. (2015) observed $\mathrm{CD} 20+\mathrm{CD} 3+$ expression in CTCL, and this coexpression has been recognized in peripheral T-cell lymphomas.
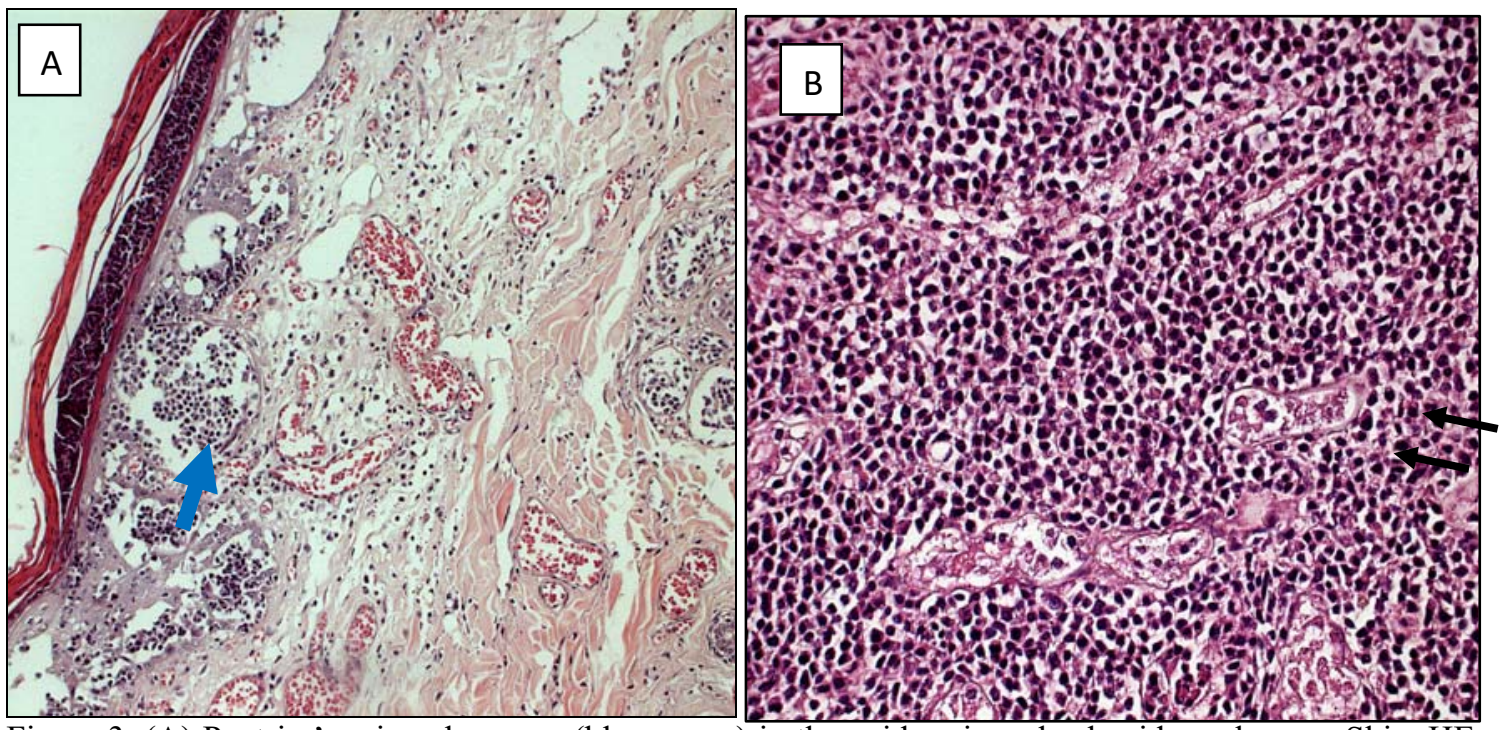

Figure 3. (A) Pautrier's microabscesses (blue arrow) in the epidermis and subepidermal areas. Skin. HE. 200X. (B) Infiltration of neoplastic lymphocytes surrounding a degenerated renal tubule (black arrow). Kidney. HE. 400X. 


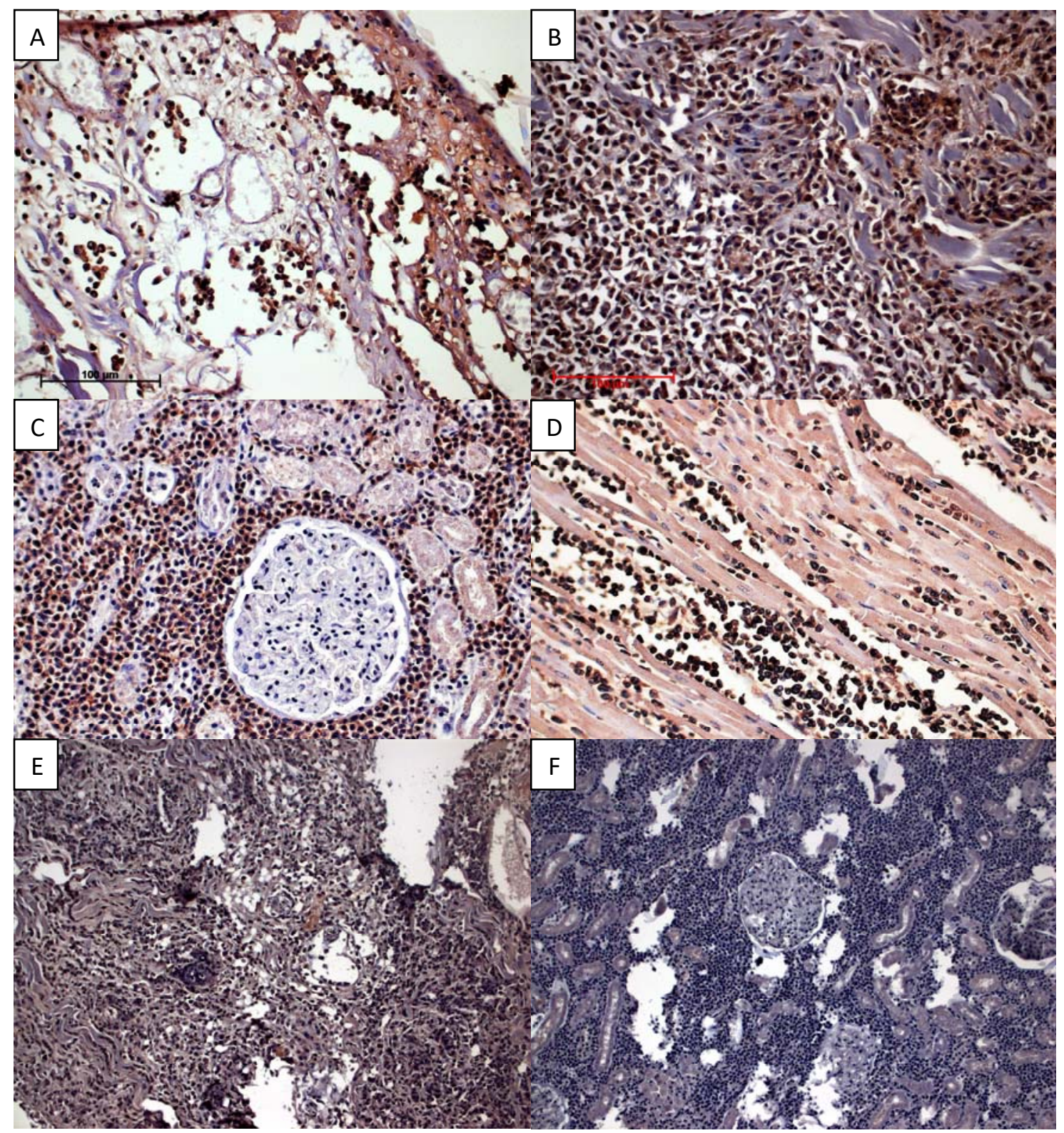

Figure 4. CD3 positive immunostaning of neoplastic T cells infiltrated in epidermis (A), dermis (B), kidney (C), and myocardium (D), 400x. CD20 negative immunostaining of neoplastic cells in the skin (E) and kidney (F), 200x. Streptavidin-biotin-peroxidase. Bar $=100 \mu \mathrm{m}$.

The World Health Organization classifies cutaneous T-cell neoplasms as epitheliotropic and nonepitheliotropic. Epitheliotropic neoplasms are normally observed in the classic nodular form (mycosis fungoides) and as pagetoid reticulosis (Martorell et al., 2011). Canine CEL are classified into two types: mycosis fungoides (MF), which is an epitheliotropic form of primary cutaneous T-cell lymphoma (CTCL) and is commonly encountered and Sezary syndrome, which is a rare leukemic variant of CTCL characterized by generalized erythroderma, intense pruritus, lymphadenopathy and leukemia (Rodigheri et al., 2007). Clinical data and additional exams, like blood tests, x-rays and ultrasound are important to help determine then type of CEL, and to early detect possible metastasis. Due to 
the absence of clinical data, Sezary syndrome could not be completely ruled out.

Although Sezary Syndrome (SS) is characterized by the simultaneous presence of cutaneous epitheliotropic lymphoma, peripheral lympoadenopathy, and circulating tumor cells in the peripheral blood (Gross et al., 2005), we believe that this case may not be a SS, based on the histopathological findings. In SS, neoplastic cells are characterized by small lymphocytes with hyperchromatic, convoluted, and/or cerebriform nuclei (Rodigheri et al., 2007), which were not observed in this case.

A study performed by Machado et al. (2015) showed that of 11 animals presenting immunohistochemical diagnosis of lymphoma, only five had the diagnosis of lymphoma by HE staining, and six had been classified as unspecific round cell neoplasia, suggesting that immunohistochemistry is essential for the differentiation of round cell neoplasia. In this case, immunohistochemistry was very important to confirm the suspicion of CTCL, given that multiple organ metastasis are very rare.

CTCL rarely metastasize (Moore et al., 1994; Yoon et al., 2014); however, when metastasis does occur, is usually restricted to a single organ (Moore et al., 1994). However, Fictum et al. (2009), and more recently, Yoon et al. (2014) described multisystemic metastasis of CTCL in dogs, both characterized by $\mathrm{CD} 3+$ neoplastic cells, as described in our study. Although there are no clinical data in this study, possibly the heart and kidney metastases contribute to the general impairment and sudden death of the dog.

\section{CONCLUSION}

We reported a rare case of canine cutaneous epitheliotropic lymphoma with metastasis in the myocardium and kidney. Histopathological and immunohistochemical findings supported the dermatological suspicion of this case. Although there was no suspicion of involvement of the internal organs, metastasis was shown to be severe and may have contributed to sudden death of the dog. Because the clinical signs of CTCL are nonspecific, it is important to examine animals with chronic skin lesion for cutaneous epitheliotropic lymphoma, and staging the tumor could be a helpful tool to look for distant organ metastasis.

\section{REFERENCES}

BRACHELENTE, C.; AFFOLTER, V.K.; FONDATI, A. et al. CD3 and CD20 coexpression in a case of canine cutaneous epitheliotropic T-cell lymphoma (Mycosis Fungoides). Vet. Pathol., v.53, p.563-566, 2015.

CZASCH, S.; RISSE, K.; BAUMGÄRTNER, W. Central nervous system metastasis of a cutaneous epitheliotropic lymphosarcoma in a dog. J. Comp. Pathol., v.123, p.59-63, 2000.

FICTUM, P.; SKORIK, M.; SEGESOVA, K.; BORSKA, P. Epitheliotropic cutaneous lymphoma (mycosis fungoides) with formation of nodal and distant metastases in a dog: a case report. Vet. Med., v.8, p.387-392, 2009.

FONTAINE, J.; HEUMANN, M.; DAY, M.J. Canine cutaneous epitheliotropic T-cell lymphoma: a review of 30 cases. Vet. Dermatol., v.21, p.267-275, 2010.

GROSS, T.L.; IHRKE, P.J.; WALDER, E.J.; AFFOLTER, V.K. Lymphocitic tumors. In:

Skin diseases of the dog and the cat: clinical and histopathologic diagnosis. 2.ed. Iwoa: Blackwell Science, 2005. p.886-893.

MACHADO, L.H.A.; PALUMBO, M.I.P.; ZAHN, F.S. et al. Comparative study of histopathology and immunohistochemistry of indefinite round cell cutaneous tumors and characterization of canine lymphoma. Arq. Bras. Med. Vet. Zootec., v.67, p.3236, 2015.

MARTORELL, J.; SUCH, R.; FONDEVILA, D.; BARDAGI, M. Cutaneous epitheliotropic T-cell lymphoma with systemic spread in a Guinea Pig (Cavia porcellus). J. Exotic Pet Med., v.20, p.313-317, 2011.

MINESHIGE, M.; KAWARAI, S.; YAUCHI, T. et al. Cutaneous epitheliotropic T-cell lymphoma with systemic dissemination in a dog. J. Vet. Diagn. Investig., v.28, p.327-331, 2016.

MOORE, P.F.; OLIVRY, T.; NAYDAN, D. Canine cutaneous epitheliotropic lymphoma (mycosis fungoides) is a proliferative disorder of CD8+ T cells. Am. J. Pathol., v.144, p.421-429, 1994.

PANAKOVA, L.; HECKERS, K.; MAJSOUB, M.; MUELLER, R.S. Cutaneous epitheliotropic T-cell lymphoma with dissemination to the liver in an eastern chipmunk (Tamias striatus). Vet. Dermatol., v.21, p.205-208, 2009.

RODIGHERI, S.M.; FARIAS, M.R.; WERNER, J. et al. Síndrome de Sézary em cadela. Arq. Bras. Med. Vet. Zootec., v.59, p.1330-1332, 2007.

YOON, J.; YU, D.; SONG, R. et al. Cutaneous epitheliotropic T-Cell lymphoma with multiple metastases in a dog diagnosed by PCR to antigen receptor rearrangement analysis. Pak. Vet. J., v.34, p.423-425, 2014. 